University of Nebraska - Lincoln

DigitalCommons@University of Nebraska - Lincoln

2014

\title{
You are not always what we think you eat: selective assimilation across multiple whole-stream isotopic tracer studies
}

\author{
W. K. Dodds \\ Kansas State University, wkdodds@ksu.edu \\ S. M. Collins \\ Cornell University \\ S. K. Hamilton \\ Michigan State University \\ J. L. Tank \\ University of Notre Dame \\ S. Johnson \\ USDA Forest Service, Pacific Northwest Research Station, Corvallis, Oregon
}

See next page for additional authors

Follow this and additional works at: https://digitalcommons.unl.edu/natrespapers

Part of the Natural Resources and Conservation Commons, Natural Resources Management and Policy Commons, and the Other Environmental Sciences Commons

Dodds, W. K.; Collins, S. M.; Hamilton, S. K.; Tank, J. L.; Johnson, S.; Webster, J. R.; Simon, K. S.; Whiles, M. R.; Rantala, H. M.; McDowell, W. H.; Peterson, S. D.; Riis, T.; Crenshaw, C. L.; Thomas, S. A.; Kristensen, P. B.; Cheever, B. M.; Flecker, A. S.; Griffiths, N. A.; Crowl, T.; Rosi-Marshall, E. J.; El-Sabaawi, R.; and Marti, E., "You are not always what we think you eat: selective assimilation across multiple whole-stream isotopic tracer studies" (2014). Papers in Natural Resources. 507.

https://digitalcommons.unl.edu/natrespapers/507

This Article is brought to you for free and open access by the Natural Resources, School of at DigitalCommons@University of Nebraska - Lincoln. It has been accepted for inclusion in Papers in Natural Resources by an authorized administrator of DigitalCommons@University of Nebraska - Lincoln. 


\section{Authors}

W. K. Dodds, S. M. Collins, S. K. Hamilton, J. L. Tank, S. Johnson, J. R. Webster, K. S. Simon, M. R. Whiles, H. M. Rantala, W. H. McDowell, S. D. Peterson, T. Riis, C. L. Crenshaw, S. A. Thomas, P. B. Kristensen, B. M. Cheever, A. S. Flecker, N. A. Griffiths, T. Crowl, E. J. Rosi-Marshall, R. El-Sabaawi, and E. Marti 


\title{
You are not always what we think you eat: selective assimilation across multiple whole-stream isotopic tracer studies
}

\author{
W. K. Dodds, ${ }^{1,20}$ S. M. Collins, ${ }^{2}$ S. K. Hamilton, ${ }^{3}$ J. L. Tank, ${ }^{4}$ S. Johnson,,${ }^{5}$ J. R. Webster,${ }^{6}$ K. S. Simon, ${ }^{7}$ \\ M. R. Whiles, ${ }^{8}$ H. M. Rantala, ${ }^{8}$ W. H. McDowell, ${ }^{9}$ S. D. Peterson,${ }^{10}$ T. Riss, ${ }^{11}$ C. L. Crenshaw,${ }^{12}$ \\ S. A. Thomas, ${ }^{13}$ P. B. Kristensen, ${ }^{11}$ B. M. Cheever, ${ }^{14}$ A. S. Flecker, ${ }^{2}$ N. A. Griffiths, ${ }^{15}$ T. Crowl, ${ }^{16}$ \\ E. J. Rosi-Marshall,${ }^{17}$ R. El-Sabahawi, ${ }^{18}$ and E. Martí ${ }^{19}$ \\ ${ }^{1}$ Division of Biology, Kansas State University, 106 Ackert Hall, Manhattan, Kansas 66506 USA \\ ${ }^{2}$ Department of Ecology and Evolutionary Biology, Cornell University, Corson Hall A406B, Ithaca, New York 14853 USA \\ ${ }^{3}$ W. K. Kellogg Biological Station, Michigan State University, Hickory Corners, Michigan 49060 USA \\ ${ }^{4}$ Department of Biological Sciences, University of Notre Dame, 100 Galvin Life Sciences Center, Notre Dame, Indiana 46556 USA \\ ${ }^{5}$ USDA Forest Service, Pacific Northwest Research Station, 3200 SW Jefferson Way, Corvallis, Oregon 97331 USA \\ ${ }^{6}$ Department of Biological Sciences, Virginia Tech, 2125 Derring Hall, Blacksburg, Virginia 24601 USA \\ ${ }^{7}$ School of Environment, University of Auckland, P.O. Box 92019, Auckland 1142 New Zealand \\ ${ }^{8}$ Department of Zoology and Center for Ecology, Southern Illinois University, Carbondale, Illinois 62901 USA \\ ${ }^{9}$ Natural Resources and the Environment, University of New Hampshire, Durham, New Hampshire 03824 USA \\ ${ }^{10}$ Watershed Studies Institute, Department of Biological Sciences, Murray State University, Murray, Kentucky 42071 USA \\ ${ }^{11}$ Department of Bioscience, Aarhus University, Ole Worms Allé 1, 8000 Aarhus C, Denmark \\ ${ }^{12}$ Department of Biology, University of New Mexico, Albuquerque, New Mexico 87131 USA \\ ${ }^{13}$ School of Natural Resources, University of Nebraska, 403 Hardin Hall, Lincoln, Nebraska 68583 USA \\ ${ }^{14}$ Department of Microbiology and Molecular Genetics, Michigan State University, East Lansing, Michigan 48824 USA \\ ${ }^{15}$ Climate Change Science Institute and Environmental Sciences Division, Oak Ridge National Laboratory, Oak Ridge, \\ Tennessee 37831 USA \\ ${ }^{16}$ Southeast Environmental Research Center and Department of Biology, Florida International University, Miami, Florida 33199 USA \\ ${ }^{17}$ Cary Institute of Ecosystem Studies, Millbrook, New York 12545 USA \\ ${ }^{18}$ Department of Biology, University of Victoria, Cunningham 202, 3800 Finnerty Road, Victoria, British Columbia V8P 5 C2 Canada \\ ${ }^{19}$ Biogeodynamics and Biodiversity Group, Centre d'Estudis Avançats de Blanes (CEAB-CSIC), Blanes, Catalonia, Spain
}

Abstract. Analyses of $21{ }^{15} \mathrm{~N}$ stable isotope tracer experiments, designed to examine food web dynamics in streams around the world, indicated that the isotopic composition of food resources assimilated by primary consumers (mostly invertebrates) poorly reflected the presumed food sources. Modeling indicated that consumers assimilated only $33-50 \%$ of the $\mathrm{N}$ available in sampled food sources such as decomposing leaves, epilithon, and fine particulate detritus over feeding periods of weeks or more. Thus, common methods of sampling food sources consumed by animals in streams do not sufficiently reflect the pool of $\mathrm{N}$ they assimilate. Isotope tracer studies, combined with modeling and food separation techniques, can improve estimation of $\mathrm{N}$ pools in food sources that are assimilated by consumers. Food web studies that use putative food samples composed of actively cycling (more readily assimilable) and refractory (less assimilable) $\mathrm{N}$ fractions may draw erroneous conclusions about diets, $\mathrm{N}$ turnover, and trophic linkages of consumers. By extension, food web studies using stoichiometric or natural abundance approaches that rely on an accurate description of food-source composition could result in errors when an actively cycling pool that is only a fraction of the $\mathrm{N}$ pool in sampled food resources is not accounted for.

Key words: ${ }^{15} \mathrm{~N}$; consumer; food resources; food web; label mismatch; nitrogen cycling; stable isotope tracer addition.

\section{INTRODUCTION}

Trophic relationships and food web structure remain a central focus of ecological research. Early food webs were constructed using simple trophic links (e.g., Elton 1927), but functional representations of food webs are more often based on quantitative flows of energy and

Manuscript received 10 December 2013; revised 27 March 2014; accepted 22 April 2014. Corresponding Editor: R. A. Dahlgren.

${ }^{20}$ E-mail: wkdodds@ksu.edu carbon (e.g., Lindeman 1942, Paine 1966, Polis and Hurd 1995, Hall et al. 2000, Cross et al. 2013) and/or biologically active elements such as nitrogen $(\mathrm{N})$ and phosphorus (P; e.g., Fry 1991, Cabana and Rasmussen 1996, Mulholland et al. 2000). Variation in the natural abundance of stable isotopes and the stoichiometry of an organism's elemental composition have been widely used to examine the flow of elements in food webs and how the composition of resources and diets of consumers constrain productivity and a variety of ecological processes (e.g., Elser et al. 2000). An accurate under- 
standing of what food resources are ingested and assimilated by consumers is central to quantitative food web studies. Identifying specific foods used by consumers is critical for quantifying the sources and fluxes of energy and nutrients across trophic levels, determining consumer growth efficiencies, and characterizing potential elemental imbalances between consumers and their food (Frost et al. 2005, 2006).

Gut-content analyses have long been used to quantify consumer diets, but the method has shortcomings because the temporal and spatial variability in food resources consumed requires frequent sampling (RosiMarshall and Wallace 2002, Wellard Kelly et al. 2013); quantification is time-consuming, especially for very small animals; detrital particles in diets are difficult to identify microscopically (e.g., amorphous detritus could be derived from leaves or algae); and assimilation efficiency varies among foods and diet proportions. Thus, estimates of assimilation based on gut-content data need to be adjusted to allow quantitative estimates of energy or material flow (Benke and Wallace 1980). While gut-content analyses can reveal functional roles of consumers associated with foraging and ingestion, additional information is required to understand which food resources are actually assimilated (e.g., Altig et al. 2007).

Variation in the natural abundances of stable isotopes (e.g., ${ }^{13} \mathrm{C},{ }^{15} \mathrm{~N},{ }^{34} \mathrm{~S}$, and ${ }^{2} \mathrm{H}$ ) has been increasingly used to characterize trophic relationships and provides an alternative (or complement) to gut-content analysis. This method relies on accurate isotopic characterization of consumers and their food resources and knowledge of trophic enrichment of the consumer relative to its diet (Layman et al. 2012). The ${ }^{15} \mathrm{~N}$ enrichment at each trophic level generally averages 3-4\% although it can be less (Minagawa and Wada 1984, Cabana and Rasmussen 1996, Vander Zanden and Rasmussen 1999). Therefore, $\mathrm{N}$ isotope ratios in consumers can indicate trophic level, an approach that offers advantages over gut-content analyses because it is logistically simpler, integrates diets over space and time, and directly reflects food that is assimilated, not simply ingested. Similarly, other isotopes have been used as food web tracers and these isotopes are often used simultaneously as natural labels to trace food web sources and material flow pathways (Peterson et al. 1985). However, natural abundance isotope approaches also have shortcomings, including uncertainties in estimating the isotopic composition of basal food web compartments that often have rapid turnover and high spatiotemporal variability; high spatial and temporal variability in isotopic content of some consumers and/or their prey; and uncertainty in the trophic enrichment of ${ }^{15} \mathrm{~N}$ (and other isotopes) associated with specific trophic steps (e.g., Cabana and Rasmussen 1996, Evans-White et al. 2001, Martínez del Río and Anderson-Sprecher 2008, Jardine et al. 2014).

Experimental tracer additions of stable isotopes can also be used to understand trophic relationships within food webs and to estimate elemental fluxes through food web compartments (e.g., Mulholland et al. 2000, Peterson et al. 2001). During ${ }^{15} \mathrm{~N}$ tracer additions of enriched ammonium or nitrate, stream biota, able to assimilate dissolved inorganic $\mathrm{N}$ directly from the water column (i.e., algae, bacteria, and fungi in biofilms), become enriched in ${ }^{15} \mathrm{~N}$, and over time that enrichment is transferred up the food web as these primary uptake compartments are consumed. The temporal pattern of isotopic enrichment in a consumer depends on the isotopic signature of its food, its assimilation efficiency, and the $\mathrm{N}$ turnover time of its tissues. In the analysis of data from isotope tracer addition experiments, diet and consumer isotope ratios are normally corrected for background isotope ratios (sampled at an upstream reference site), thereby factoring out the uncertain effect of trophic enrichment on diet-consumer comparisons. Furthermore, trophic fractionation of isotopes is generally small compared to the isotope signatures created by the tracer additions.

Numerous ${ }^{15} \mathrm{~N}$-isotope addition experiments have been conducted to examine food webs in terrestrial (e.g., Nadelhoffer et al. 1999), marine (e.g., Veuger et al. 2007), and freshwater (e.g., Mulholland et al. 2000) environments. Such studies hold promise for clarifying trophic relationships by experimentally tracking elemental fluxes through food webs. However, few isotope tracer studies have addressed trophic dynamics of food webs in detail, in part, due to difficulties in interpreting the pattern of isotopic labeling between basal food resources and consumers. This study focuses on ${ }^{15} \mathrm{~N}$, but our conclusions can be extended to other isotopic tracers that might be employed in food web studies.

Results from the lotic intersite nitrogen experiment (LINX) and subsequent experiments based on similar ${ }^{15} \mathrm{~N}$ tracer addition approaches, have revealed an apparent and consistent discrepancy between the tracer ${ }^{15} \mathrm{~N}$ enrichment of basal food resources and consumers of those resources, in that consumers often become more enriched with the tracer isotope than sampled food resources (e.g., Tank et al. 2000, Hamilton et al. 2004). This "label mismatch" may result from inaccurate sampling of food resources and/or differential ingestion or assimilation of materials within the food samples. For example, epilithon (biofilm growing on rocks) is commonly assumed to be a food source for grazers in streams and consists of a complex mixture of algae, heterotrophic microbes, and non-living (detrital) organic matter. Epilithon is often sampled by scraping bulk material off rock surfaces, but grazing invertebrates may selectively ingest and/or assimilate the more actively cycling components of the epilithon, which can result in consumer isotope labeling that exceeds that observed in the bulk food resource.

Collective analyses of data from the LINX studies and a growing number of similar experiments indicate numerous cases of label mismatch in which the maximum tracer ${ }^{15} \mathrm{~N}$ enrichment of animals (particu- 
TABLE 1. Site location and discharge of the study sites during the tracer releases.

\begin{tabular}{|c|c|c|c|c|c|}
\hline Acronym & Stream name & Latitude $\left(^{\circ}\right)$ & Longitude $\left({ }^{\circ}\right)$ & Discharge $(\mathrm{L} / \mathrm{s})$ & Citation \\
\hline BBNY & Blues Brook, USA & 43.67 & -74.94 & 5.0 & \\
\hline BBNH & Bear Brook, USA & 43.93 & -71.75 & 9.1 & \\
\hline $\mathrm{BCNC}$ & Upper Ball Creek, USA & 35.05 & -83.43 & 129.6 & Tank et al. (2000) \\
\hline CBNY & Combs Brook, USA & 43.67 & -74.94 & 5.0 & \\
\hline E1AK & E1 Alaska, USA & 68.63 & -149.63 & 134.0 & \\
\hline ECMI & Eagle Creek, USA & 42.33 & -85.33 & 202.0 & Hamilton et al. (2001) \\
\hline EVNT & Rio Maria, Panama & 8.64 & -80.04 & 22.9 & Whiles et al. (2013) \\
\hline EVWT & Rio Maria, Panama & 8.64 & -80.04 & 22.4 & Whiles et al. (2013) \\
\hline GCNM & Gallina Creek, USA & 36.58 & -105.58 & 4.0 & \\
\hline KCKS & S. Kings Creek, USA & 39.08 & -96.58 & 15.8 & Dodds et al. (2000) \\
\hline KGNZ & Kye Burn, New Zealand & -44.95 & 170.35 & 22.3 & Simon et al. (2004) \\
\hline KTNZ & Kye Burn, New Zealand & -44.95 & 170.35 & 34.6 & Simon et al. (2004) \\
\hline LIDK & Lilleaa, Denmark & 56.25 & 10.05 & 63.2 & Riis et al. (2012) \\
\hline MCOR & Mack Creek, USA & 44.20 & -122.15 & 56.6 & Ashkenas et al. (2004) \\
\hline QBPR & Quebrada Bisley, USA & 18.32 & -65.75 & 20.2 & Merriam et al. (2002) \\
\hline SBIC & Steinbogalaekur, Iceland & 65.53 & -17.02 & 156.4 & \\
\hline SCAZ & Sycamore Creek, USA & 33.75 & -111.5 & 43.0 & \\
\hline ULTD & Upper La Laja, Trinidad and Tobago & 10.49 & -61.30 & 14.0 & \\
\hline WBTN & Walker Branch, USA & 35.97 & -84.28 & 17.5 & Mulholland et al. (2000) \\
\hline
\end{tabular}

Notes: The last two letters of the acronym are abbreviations for the state or country of the site. Citations of original studies are indicated. For latitude, positive values are north and negative values are south. For longitude, positive values are east and negative values are west.

larly primary consumers) ranged from $10 \%$ to over $200 \%$ (delta $[\delta]$ units or per mil [Fry 2006]) above their presumed food source. The logical explanation for the label mismatch is that field sampling of food resources in these studies did not accurately represent the $\mathrm{N}$ isotopic composition of the food assimilated by the consumer. The few studies that have applied techniques to separate algae from detrital organic matter using density separation by centrifugation in colloidal silica suggest that much of this discrepancy can be accounted for by the isotopic differences between highly active/labile portions of the food compared with more refractory material in the bulk resource (Hamilton et al. 2001, 2005).

Here, we explore the relationship between isotope tracer accumulation in stream consumers and their presumed food resources using data from 21 experimental ${ }^{15} \mathrm{~N}$ tracer additions in streams ranging from tropical to arctic biomes. We address how well ${ }^{15} \mathrm{~N}$ tracer measured in samples of putative food sources matches the ${ }^{15} \mathrm{~N}$ tracer in consumers, and how we can correct for the contribution of less assimilable $\mathrm{N}$ that is included in samples of primary uptake compartments. In order to accurately describe the observed trends in the collective food web data, we used a modeling approach to fit observed data and draw conclusions about how well we sampled food resources for different consumer groups compared to what they ultimately assimilated. We then present recommendations for how future isotope enrichment experiments, natural abundance studies, and stoichiometric research on food webs can more accurately capture consumer-resource relationships.

\section{Methods}

Detailed methods and data from the majority of the 21 experiments included in this study have been published previously, and methods from all experiments stem from a common set of protocols used in the original LINX study. Additional details can be found in the references in Table 1, particularly Mulholland et al. (2000), Tank et al. (2000), and Webster et al. (2003). Briefly, at each site ${ }^{15} \mathrm{~N}$-ammonium $\left({ }^{15} \mathrm{~N}-\mathrm{NH}_{4}\right)$ was added to the stream for 5-42 days resulting in water column $\delta^{15} \mathrm{~N}^{-} \mathrm{NH}_{4}>100 \%$ (most were $>1000 \%$ ).

The study sites used in this analysis included streams from North America, the Caribbean, Central America, New Zealand, Denmark, and Iceland; sites ranged from tropical to arctic, but the majority were temperate. All ${ }^{15} \mathrm{~N}$ tracer additions were conducted in relatively small streams (most discharges $<100 \mathrm{~L} / \mathrm{s}$; Table 1). Food resources and consumers (largely invertebrates) were sampled for tracer ${ }^{15} \mathrm{~N}$ content as described in the papers referenced in Table 1, using techniques that are common in stream ecology research. Presumed food resources included biofilms scrubbed from rocks (epilithon for grazers), fine detritus suctioned from sediments or suspended in the water column (for collectors and filterers, respectively), pieces of detritus (leaves, wood for shredders), macrophytes, and macroinvertebrates for predators. Consumers were categorized based on functional feeding groups (e.g., collector-gatherers, filterers, grazers, shredders, and predators), and those that consumed more than one food source were classified as omnivores.

\section{Modeling}

The model uses a linked dynamic compartment approach based on observed isotopic enrichment of food and consumers, hereafter referred to as food pool (FP) and consumer pool (CP). Note that we refer to ecosystem compartments as pools of $\mathrm{N}$, not to be confused with pools and riffles found in streams. The 
data were collected over time as the system was enriched with tracer ${ }^{15} \mathrm{~N}$, and as ${ }^{15} \mathrm{~N}$ declined after the addition stopped (Wollheim et al. 1999, Dodds et al. 2000, Whiles et al. 2013). In this model, both the ${ }^{15} \mathrm{~N}$ and ${ }^{14} \mathrm{~N}$ mass in each pool (in units of $\mathrm{mmol} / \mathrm{m}^{2}$ ) were tracked over time, and gains and losses of isotopes were based on uptake ( $U_{15 \mathrm{~N}}$ and $\left.U_{14 \mathrm{~N}}\right)$ and $\operatorname{loss}\left(L_{15 \mathrm{~N}}\right.$ and $\left.L_{14 \mathrm{~N}}\right)$ of both isotopes expressed as mass per unit area per unit time $(t)$. These uptake and loss fluxes were calculated by tracking the ${ }^{15} \mathrm{~N}$ and ${ }^{14} \mathrm{~N}$ in the consumer pool $\left(\mathrm{CP}_{15 \mathrm{~N}}\right.$ and $\mathrm{CP}_{14 \mathrm{~N}}$, respectively) as a function of the $\delta^{15} \mathrm{~N}$ of up to three potential food pools labeled a, b, and c $\left(\mathrm{FP}_{\delta 15 \mathrm{~N}, \mathrm{a}}\right.$; $\left.\mathrm{FP}_{\delta 15 \mathrm{~N}, \mathrm{~b}} ; \mathrm{FP}_{\delta 15 \mathrm{~N}, \mathrm{c}}\right)$.

The composite food pool $\delta^{15} \mathrm{~N}\left(\mathrm{FP}_{\delta 15 \mathrm{~N}}\right)$ was estimated by weighting the $\delta^{15} \mathrm{~N}$ of individual diet sources $\left(\mathrm{FP}_{\delta 15 \mathrm{~N}, \mathrm{a}}\right)$ by the proportion of that food source in the consumer diet $\left(P_{\mathrm{a}}\right.$; Eq. 1). The proportion of each food source was estimated using knowledge of consumer diets obtained through previous research examining gut contents. For the most part, these determinations were based on previously published research from each site (e.g., Evans-White et al. 2003, Frauendorf et al. 2013). For organisms that were presumed to eat fewer than three food sources, the number of sources was reduced accordingly

$$
\begin{aligned}
\mathrm{FP}_{\delta 15 \mathrm{~N}}= & \mathrm{FP}_{\delta 15 \mathrm{~N}, \mathrm{a}} \times P_{\mathrm{a}}+\mathrm{FP}_{\delta 15 \mathrm{~N}, \mathrm{~b}} \times P_{\mathrm{b}} \\
& +\mathrm{FP}_{\delta 15 \mathrm{~N}, \mathrm{c}} \times P_{\mathrm{c}} .
\end{aligned}
$$

The ${ }^{15} \mathrm{~N}$ atomic ratios of the FP (ARFP) and CP (ARCP) were calculated from $\delta^{15} \mathrm{~N}$ values to allow separate mass-balance tracking of ${ }^{15} \mathrm{~N}$ and ${ }^{14} \mathrm{~N}$

$$
\begin{aligned}
\mathrm{ARFP}=\frac{\mathrm{FP}_{15 \mathrm{~N}}}{\mathrm{FP}_{14 \mathrm{~N}}+\mathrm{FP}_{15 \mathrm{~N}}}= & \left(\mathrm{FP}_{\delta 15 \mathrm{~N}} / 1000\right) \times 0.003663 \\
& +0.003663
\end{aligned}
$$

where 0.003663 is the AR of the standard (atmospheric $\mathrm{N}_{2}$ ).

At each sampling point, the ${ }^{15} \mathrm{~N}$ and ${ }^{14} \mathrm{~N}$ fluxes into the consumer pool were assumed to be proportional to the atomic ratio of the food pool(s), and $\mathrm{N}$ uptake and loss were the sum of the ${ }^{15} \mathrm{~N}$ and ${ }^{14} \mathrm{~N}$ uptake rates $\left(U_{15 \mathrm{~N}}\right.$ and $U_{14 \mathrm{~N}}$, respectively)

$$
U=U_{15 \mathrm{~N}}+U_{14 \mathrm{~N}}
$$

The change in the consumer pool of ${ }^{15} \mathrm{~N}$, between time steps one and two, representing the time $(t)$ between sampling, was used to calculate the new size of the consumer pool at time step two $\left(\mathrm{CP}_{15 \mathrm{~N}, t=2}\right)$ from net uptake, which depends on ARFP and the uptake from the FP over time, as well as the loss from the CP $(L)$, the atomic ratio of the consumer pool (ARCP), and time

$$
\begin{aligned}
\mathrm{CP}_{15 \mathrm{~N}, t=2}= & \mathrm{CP}_{15 \mathrm{~N}, t=1}+(U \times \operatorname{ARFP} \times t) \\
& -(L \times \mathrm{ARCP} \times t) .
\end{aligned}
$$

Similarly, net uptake of ${ }^{14} \mathrm{~N}$ was calculated as

$$
\begin{aligned}
\mathrm{CP}_{14 \mathrm{~N}, t=2}= & \left.\mathrm{CP}_{14 \mathrm{~N}, t=1}+U \times[1-\mathrm{ARFP}] \times t\right) \\
& -(L \times[1-\mathrm{ARCP}] \times t) .
\end{aligned}
$$

The calculated ARCP can lead to model instability if the time steps are too large (i.e., many days between samples). Thus, ARCP was reset to the observed value at each sampled time step in the model. Equations of Laws (1984) were used to weight changes in ARCP and ARFP over time because straight means are not appropriate in this case.

The loss term $(L)$ represents any loss from the consumer pool including excretion, drift, predation, and emergence. The ratio of the total uptake to total loss was used to determine if there was mass loss or gain. If the biomass of $\mathrm{CP}$ was constant over the time period, then $U=L$. In cases where there were changes in $\mathrm{N}$ mass over time, then the ratio of $U$ to $L$ required estimation.

We created a multiplier $(M)$ to evaluate the degree to which we were not accounting for $\delta^{15} \mathrm{~N}$ label mismatch in the food pool by adjusting the peak food source label to fit the observed peak animal isotopic signal. The bounds on the range of $M$ values were set such that the lowest possible value for $M$ adjusted the food source to match the $\delta^{15} \mathrm{~N}$ of its consumer $\left(\mathrm{CP}_{15 \mathrm{~N}} / \mathrm{FP}_{15 \mathrm{~N}}\right)$. In contrast, the highest $M$ value was dependent on the measured or calculated $\delta^{15} \mathrm{~N}_{-} \mathrm{NH}_{4}{ }^{+}$in the water column during the experiment ( Water $_{15 \mathrm{~N}} / \mathrm{FP}_{15 \mathrm{~N}}$ ).

The model was created in Microsoft Office Excel 2007 and the "Solver" function was used to fit observed to modeled values of $\delta^{15} \mathrm{~N}$ by minimizing the sum of square of errors and changing $U, U / L$, and $M$. If there was no change in biomass over the experiment, then $U / L$ was set to one. If there was a change in biomass, a preliminary run was used to ensure that the total mass change was correct, and in this case $U / L$ and $U$ were changed to minimize the difference between observed and modeled final biomass based on the sum of squared errors and accumulation of ${ }^{14} \mathrm{~N}$ and ${ }^{15} \mathrm{~N}$. However, the total mass change was very insensitive to ${ }^{15} \mathrm{~N}$ mass, as it was a small portion of the total $\mathrm{N}$ mass, even in highly labeled compartments. Once the $U / L$ was set, then the model was used to fine-tune the values of $U$ and $M$ to match observed and modeled $\delta^{15} \mathrm{~N}$.

In all cases, the model output was also observed graphically to assess the quality of fit. While we recognize this to be a somewhat subjective approach, mathematical search methods that are designed to minimize error can find locally stable solutions that do not match the observed data. In cases where this occurred, the initial estimates were adjusted manually to provide parameters that produced predicted values that more closely fit observed values and then the automated fitting procedure was reinitiated using the new seed values. We also recognize the criticisms associated with using the Solver function in Excel to fit functions (e.g., McCullough and Heiser 2008), and that solving for multiple parameters can lead to potential errors by changing the fit of one parameter to 
compensate for another. Synthetic data sets were created with known multipliers (i.e., 1/[proportion of refractory $\mathrm{N}]$ ) and a variety of animal turnover rates were used to test the model in an effort to address this concern. Using synthetic data sets with samples at approximately the same frequency maximum as sampled in most experiments (seven days), the model found the best fit value for $M$ and estimated parameters accurately (observed vs. expected fits of $M$ had a slope not significantly different from one and were highly significant, $P<0.0001, r^{2} \approx$ 1) indicating the modeling approach we used was effective.

\section{Results \\ The transfer of tracer ${ }^{15} \mathrm{~N}$ from basal resources such} as algae and bacteria into consumers could not always be accurately modeled without using a multiplier to correct for the mismatch between tracer ${ }^{15} \mathrm{~N}$ observed in the presumed food sample and the consumer. Overall, across all our sites, 90 pairs of consumers and their food sources were modeled, and of those, 41 pairs (45\%) had consumers whose ${ }^{15} \mathrm{~N}$ enrichment exceeded that of their presumed food (Table 2), most by a considerable amount. Isotopic mismatches were observed at all but one site (Table 2) and included consumers eating all types of food resources. Overall, $58 \%$ of primary consumers became more labeled than their food sources. In contrast to the primary consumers, label mismatch in secondary consumers was much less common, with $<5 \%$ of secondary consumers showing greater tracer $\delta^{15} \mathrm{~N}$ label than their presumed food sources (Table 2).

A representative plot of observed $\delta^{15} \mathrm{~N}$ in the grazing mayfly Stenonema spp. from Walker Branch, Tennessee, USA, (Fig. 1A) demonstrates how a consumer became more labeled than its putative food source after 35 days of ${ }^{15} \mathrm{~N}-\mathrm{NH}_{4}{ }^{+}$tracer addition. First, the measured $\delta^{15} \mathrm{~N}$ label in the epilithon indicated that the sampled food source had reached isotopic equilibrium in $\sim 25$ days, stabilizing at a value that was approximately one-sixth of the $\delta^{15} \mathrm{~N}_{-} \mathrm{NH}_{4}{ }^{+}$in the water column, and only decreasing after the tracer addition was terminated on day 42. Second, fitting a multiplier to the epilithon food source resulted in the modeled food source being more highly labeled than the consumer (Fig. 1B). The model yielded values of the $\delta^{15} \mathrm{~N}$ for Stenonema that matched the observed $\delta^{15} \mathrm{~N}$ after the multiplier $(M)$ was included for the food source (Fig. 1C).

Overall, there was considerable variability in the degree of mismatch between consumers and their presumed food when consumers were examined across functional feeding groups, with higher multipliers in primary consumers (Fig. 2A) spanning groups that are likely feeding on diverse basal resources (e.g., epilithon, leaves, suspended particulate organic $\mathrm{N}$, or fine benthic organic $\mathrm{N}$ ). The median multiplier across primary consumers ranged from approximately two to three, suggesting that only about one-half to one-third of the $\mathrm{N}$ in food sampled (i.e., primary uptake compartments)
TABLE 2. Number of consumers modeled per site and number of cases where the tracer ${ }^{15} \mathrm{~N}$ label in the focal animal exceeded that in its presumed food source.

\begin{tabular}{|c|c|c|c|c|}
\hline \multirow[b]{2}{*}{$\begin{array}{c}\text { Stream } \\
\text { abbreviation }\end{array}$} & \multicolumn{2}{|c|}{ Primary consumers } & \multicolumn{2}{|c|}{ Secondary consumers } \\
\hline & Modeled & $\begin{array}{l}\text { Exceeding } \\
\text { food }\end{array}$ & Modeled & $\begin{array}{l}\text { Exceeding } \\
\text { food }\end{array}$ \\
\hline BBNY & 2 & 1 & 1 & 0 \\
\hline $\mathrm{BCNC}$ & 5 & 3 & 1 & 0 \\
\hline CBNY & 2 & 0 & 1 & 0 \\
\hline E1AK & 3 & 3 & & \\
\hline ECMI & 4 & 4 & & \\
\hline EVNT & 5 & 2 & 4 & 1 \\
\hline EVWT & 5 & 1 & 4 & 0 \\
\hline GCNM & 3 & 2 & & \\
\hline KCKS & 4 & 2 & 2 & 0 \\
\hline KGNZ & 1 & 1 & 1 & 0 \\
\hline KGNZ & 2 & 0 & 1 & 0 \\
\hline KTNZ & 1 & 1 & 1 & 0 \\
\hline KTNZ & 3 & 2 & 1 & 0 \\
\hline LIDK & 4 & 2 & 2 & 0 \\
\hline MCOR & 5 & 4 & 1 & 0 \\
\hline QBPR & 4 & 3 & & \\
\hline SBIC & 3 & 2 & & \\
\hline SCAZ & 4 & 2 & & \\
\hline UPTD & 3 & 2 & 1 & 0 \\
\hline WBTN & 6 & 3 & & \\
\hline Total & 69 & 40 & 21 & 1 \\
\hline
\end{tabular}

Note: Blank cells indicate no data, and, of the four omnivores (which are not listed on this table), none exceeded the weighted estimation of label in their food.

was assimilated by consumers. Rank analysis of the multipliers required for best model fits indicated that functional groups of primary consumers were not significantly different from each other (ANOVA, $P>$ $0.05)$ and invertebrate predators had significantly lower multipliers (ANOVA, $P<0.05$ ) than functional feeding groups that consume basal resources directly (primary consumers). Vertebrate predators had similarly low multipliers but were not included in the ANOVA due to their small sample size ( $n=5$ predators).

Several taxa modeled in this study are known to be omnivorous, eating more than one food source (see Eq. 1), so data were also analyzed by food source. The median multipliers were similar across primary food sources (Fig. 2B), however, within any single food source there was considerable variation. All food resources had minimum multiplier values of one and all but one had maximum values $>10$. Animal material (i.e., prey for predators) was the exception, with multipliers that were significantly more constrained than the other food sources. Since most animals were assumed to feed from one food compartment, foodspecific results did not vary substantially from the functional feeding group analyses.

\section{DisCUSSION}

Our synthesis of $21{ }^{15} \mathrm{~N}$ isotope tracer experiments provides clear evidence that primary consumers in streams assimilated food resources that differ from the material collected by standard methods used in stream food web studies, resulting in an apparent mismatch in 

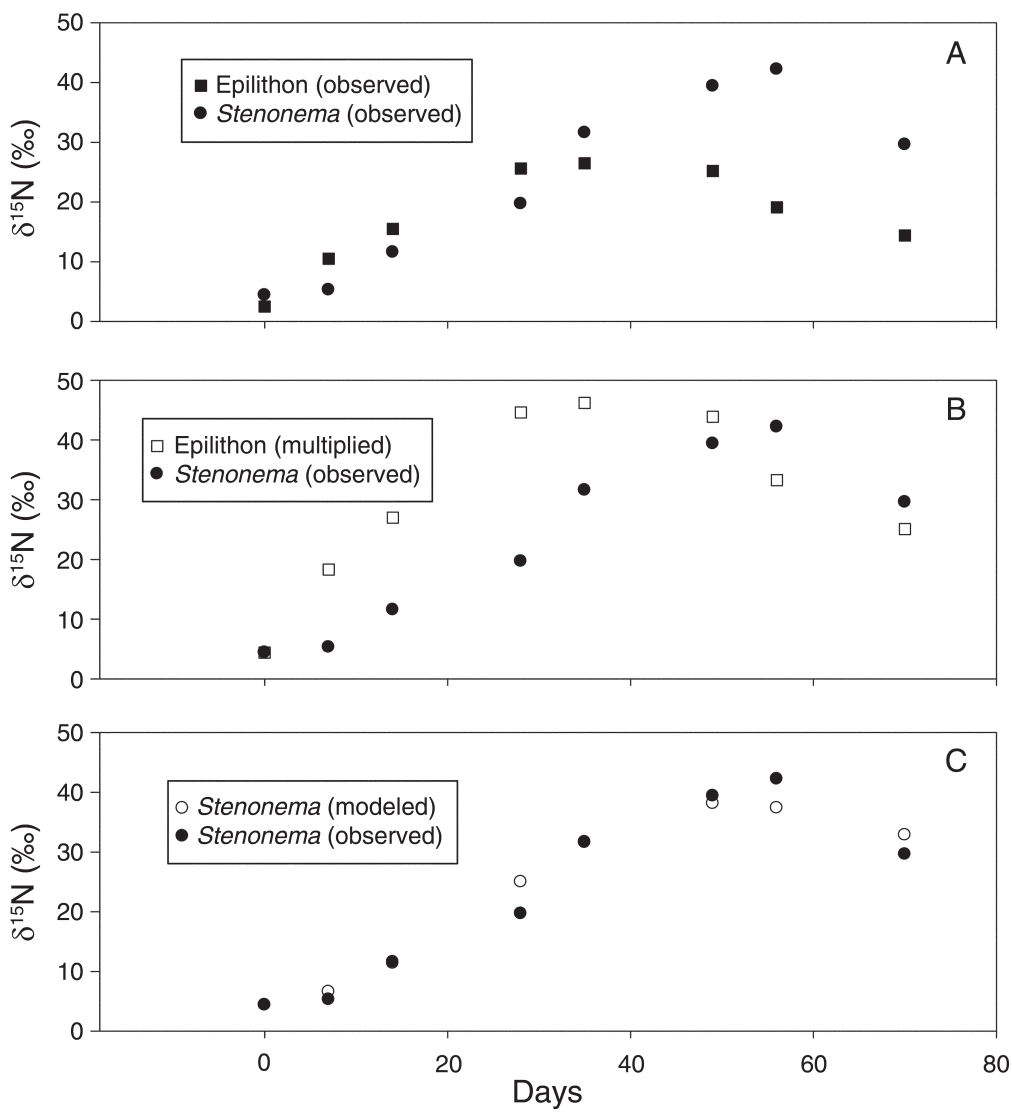

FIG. 1. Modeled and observed tracer ${ }^{15} \mathrm{~N}$ label for epilithon and the grazer Stenonema spp. in a 42 -day ${ }^{15} \mathrm{~N}$ addition at Walker Branch, Tennessee, USA (WBTN). All observed data from Mulholland et al. 2000. (A) The observed tracer ${ }^{15} \mathrm{~N}$ of epilithon and Stenonema demonstrated that the grazer became more labeled than its putative food source and that the label in the food reached plateau by day 25. (B) The model-estimated food label shows the ${ }^{15} \mathrm{~N}$ of the corrected food label peaks before the grazer does (a multiplier has been used that corrects the food source for the proportion of available N). (C) The modeled tracer ${ }^{15} \mathrm{~N}$ label in the grazer after correction of the epilithon pool and adjustment of uptake rates compared with the observed label in the field samples. In cases where the modeled value is not visible, it was very close to the observed value. Note that modeled values are represented by open symbols.

the isotopic labeling of consumers relative to their presumed food. The mismatch between food sources collected in these studies and those actually assimilated by consumers could be due to either selective ingestion or preferential assimilation of materials that are isotopically enriched relative to the sampled food matrix, and likely of higher nutritional quality. Animals can alter their diets to optimally forage for multiple elements leading to selective ingestion (Simpson et al. 2004, McNeely et al. 2009, Hawlena and Schmitz 2010). Less is known about $\mathrm{N}$ pools that are ingested but refractory to assimilation (as discussed subsequently). Most streams have at least some omnivorous animals (Gessner et al. 1999, Crowl et al. 2001). Omnivory and the prevalence of fine-particle feeding can make it challenging to connect resource availability, food ingestion as indicated by gut analyses, and nutrient cycling dynamics.

The resulting label-mismatch problem, often observed in stream isotope tracer experiments, highlights our inability to accurately sample and analyze food resourc- es assimilated by consumers. This problem is not limited to isotope enrichment studies; sampling representative food sources also is essential for both natural abundance stable isotope studies and for many stoichiometric applications, although the consequences of inaccurate sampling of food resources may be less obvious in those studies. Our assessment of multiple ${ }^{15} \mathrm{~N}$ tracer additions suggests that much of the uncertainty commonly observed in such studies may be a consequence of our inability to accurately quantify the isotopic signature of the basal food resources that are assimilated by consumers.

Fitting our model to synthetic data sets suggested that both turnover rates and multipliers can be accurately predicted as long as the food and the consumer pools both exhibit an increase and subsequent decrease in isotopic label over time, highlighting the need to conduct sampling both during and after the isotopic tracer addition. This requirement stems from the information content of each data set upon which we base our datafitting approach. Information included in these experi- 
ments includes whether the isotopic labels in the pools reach an equilibrium plateau or not; the timing of peak labeling of both food and consumers; and the magnitude of peak labeling. This information was clear for most primary consumers in our dataset, and the ability of our model to fit observed patterns in isotope labeling (e.g., Fig. 1) provides confidence that these multipliers accurately reflect selective assimilation in stream food webs.

Our findings pose a fundamental challenge for studies of food webs, as well as the stoichiometry of feeding relationships, because few studies have been able to isolate and quantify the specific component of basal food resources that consumers ingest and/or assimilate (for examples of studies that have, see Hamilton et al. 2001, 2005). Our data were obtained from streams, but we suspect that this issue is prevalent in systems where consumers forage in mixtures of fine particulate organic matter of varying nutritional quality, including suspended matter, soils, sediments, and biofilms.

Our analyses suggest that the challenge of tracing the flows of $\mathrm{N}$ in a stream food web exists for all types of food eaten by primary consumers. The basal food resources sampled in these streams are composed of a mixture of $\mathrm{N}$ that is actively cycling (e.g., algae, bacteria, fungi, and microfauna) and refractory (e.g., detrital organic compounds of various forms). Nearly all the primary consumers in these studies either selectively ingested or differentially assimilated more actively cycling fractions of the bulk food mixtures.

Carbon assimilation studies have documented severalfold greater assimilation efficiencies for omnivorous fish (Campostoma) and crayfish (Orconectes) fed animal tissue as opposed to leaf, algal, and detrital material (Evans-White et al. 2003). Less is known about organic $\mathrm{N}$ assimilation efficiencies but the pattern is expected to be similar. Organic $\mathrm{N}$ in food varies by source and digestibility. As detritus decomposes, there is an increase in the proportion of refractory organic $\mathrm{N}$ (e.g., humic compounds and chitin), that may increase total $\mathrm{N}$ content (if carbon is reduced more substantially), but reduce amino acid or protein content (Rice 1982). Amino acid content varies widely across food sources with $\sim 10 \%$ amino acid or protein as a percentage of ashfree dry mass in detritus, $\sim 23 \%$ for microalgae, and up to $\sim 60 \%$ for macroinvertebrates (Bowen 1987). Proteinrich foods can be easily assimilated by animals (Gerking 1984). With respect to less-easily assimilated compounds, fungi can range from $2 \%$ to $21 \%$ chitin by dry mass (Blumenthal and Roseman 1957), and humic materials may contain up to $6 \% \mathrm{~N}$ (Wetzel 2001).

At higher trophic levels, isotopic signatures of prey and their predators showed less label mismatch. However, predators are expected to take longer to reach isotopic equilibrium with their food resources than primary consumers, and the duration of these ${ }^{15} \mathrm{~N}$ tracer additions may not have been long enough for mismatches to become apparent (Hamilton et al. 2004).
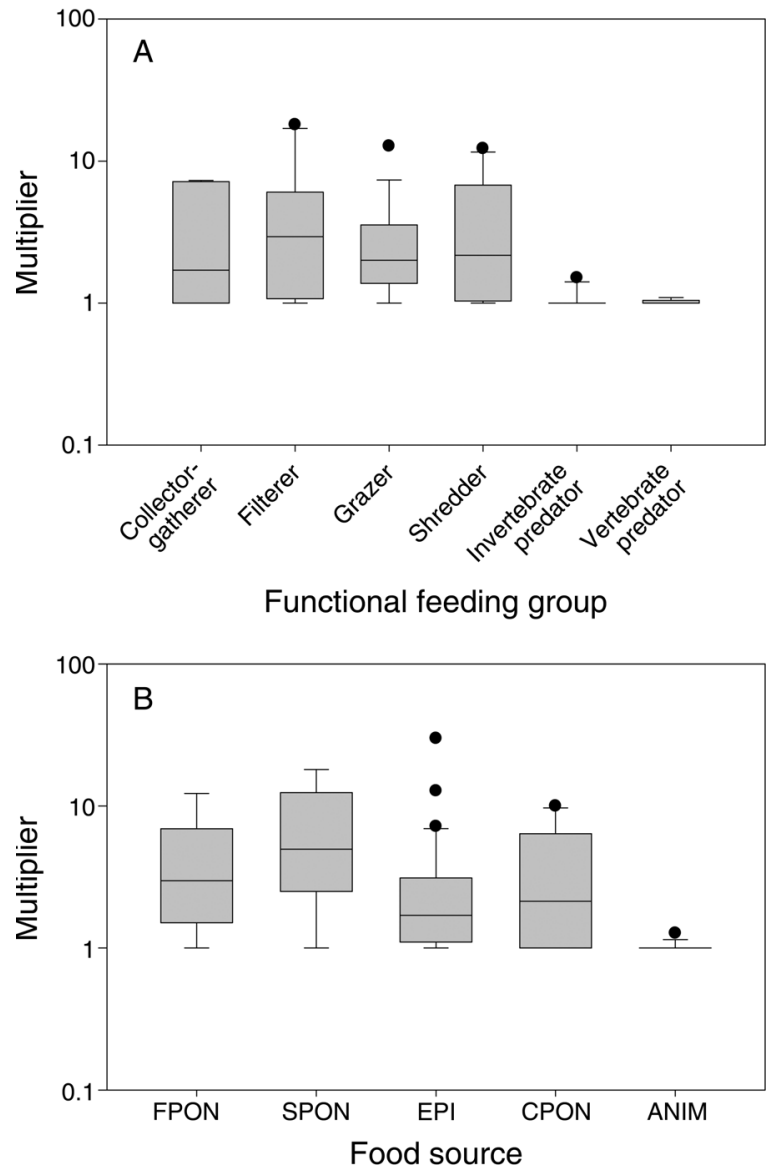

FIG. 2. Multipliers by (A) functional feeding group and (B) food source. Panel (A) shows the feeding groups collectorgatherers, filterers, grazers, shredders, invertebrate predators, and vertebrate predators. Vertebrate predators were not included in the ANOVA due to their small sample size $(n=5$ predators). In panel (B), FPON is fine particulate organic $\mathrm{N}$, SPON is suspended particulate organic N, EPI is epilithon, CPON is coarse particulate organic N, and ANIM is animal prey. The lower boundary of the boxes indicate the 25th percentile; the line within the box marks the median; and the upper boundary of the box indicates the 75 th percentile. Error bars above and below the box indicate the 90th and 10th percentiles, respectively. Points outside those regions are plotted as circles. Invertebrate predators (see panel A) and animal food sources (see panel B) were significantly different from the other groups (ANOVA, $P<0.05$ ).

Stated differently, there is less information content to inform our models when isotopic label does not reach equilibrium. Nevertheless, our data are consistent with the assumption that animal tissue is more readily assimilated than basal food resources consumed by primary consumers. It is not surprising that investigators are better able to sample predator food sources (i.e., other animals) than the dietary material of primary consumers (complex mixtures of organic matter).

Omnivores are particularly difficult to deal with in stable-isotope food web studies because they cannot be compared to a single food resource, and gut analyses do 
not accurately reflect proportions of sources assimilated. For example, two coexisting shrimp species from Puerto Rican streams, Atya and Xiphocaris, have been considered to be a grazer and a shredder, respectively, based on field and laboratory observations of feeding behavior. However, stable isotope evidence indicates Xiphocaris is not exclusively a shredder because its tissue isotopic signature can be strongly influenced by algal biofilm in high-light streams (March and Pringle 2003). Our modeling of these species in the Puerto Rican LINX experiment (Quebrada Bisley; QBPR, Table 1) was consistent with Atya as a grazer, in that it exceeded the label observed in epilithon. However, labeling of Xiphocaris did not exceed that observed in leaf or algal material, suggesting it may be a shredder in that stream.

Our results indicate that a significant proportion of the $\mathrm{N}$ in stream primary uptake compartments is refractory and cycling at rates too slow to be detected using these approaches (sensu Newbold et al. 1983). It is likely that refractory or slowly cycling $\mathrm{N}$ pools are common where there is greater $\mathrm{N}$ limitation (i.e., higher $\mathrm{C}: \mathrm{N}$ ratios) because these compartments tend to have low $\mathrm{N}$ turnover rates (Dodds et al. 2004). However, many factors likely influence the proportion of refractory $\mathrm{N}$ in materials, and $\mathrm{C}: \mathrm{N}$ alone, as well as other abiotic factors measured in these tracer studies, did not significantly correlate with our multiplier values (data not shown).

The conclusions of this study generally agree with those from Hamilton et al. (2001), who used densitygradient centrifugation methods to separate biologically active materials that were isotopically enriched from more refractory fractions of the bulk food resource in a woodland stream in Michigan (ECMI, Table 1). Hamilton et al. (2001) found that the proportion of actively cycling $\mathrm{N}$ in basal food resources was variable; $23 \%$ was active $\mathrm{N}$ in epilithon, $1 \%$ in fine benthic organic matter, $5 \%$ in small pieces of decomposing wood, and $7 \%$ in decomposing leaves. Our estimates for the proportion of actively cycling $\mathrm{N}$ in basal food resources bracket those of Hamilton et al. (2001), but our median values were higher for most food sources.

Our findings have implications for isotopic tracer experiments, as well as approaches that use natural isotope abundance for characterizing food web dynamics. If tracer ${ }^{15} \mathrm{~N}$ has reached long-term isotopic equilibrium in a food resource, then bulk collections should be a reasonable proxy for isotopic abundance in food sources. However, equilibration of refractory pools might take months or years to achieve. If inputs of ${ }^{15} \mathrm{~N}$ to food resources are reasonably constant over time, the refractory and active $\mathrm{N}$ pools should approach similar isotopic values, with the exception of allochthonous materials, and this would be true for both isotopic tracer experiments and natural abundance studies. However, our results indicate that isotopic tracer additions of at least several months would be needed for refractory materials to reach equilibrium conditions; we had many experiments where equilibrium was not reached in six weeks, and this was particularly pronounced in predators (e.g., Ashkenas et al. 2004, Hamilton et al. 2004). Larger consumers (e.g., fish and mussels), often have greater body mass and slower ${ }^{15} \mathrm{~N}$ uptake rates than their prey, and as a result during a tracer addition they require more time to reach isotopic equilibrium relative to their prey.

Quantifying the size of the readily assimilated $\mathrm{N}$ pool in isotope tracer studies is required to measure the specific activity of the label and calculate $\mathrm{N}$ flux rates between food web compartments. We are aware of few studies, other than those analyzed here, that allow for this determination. We speculate that in lakes and the open ocean, the natural abundance of suspended particulate materials might more closely represent the isotopic composition of animal diets because most of the refractory $\mathrm{N}$ is in the dissolved organic $\mathrm{N}$ pool (Aluwihare et al. 2005). In soils, pulses of $\mathrm{N}$ that are available for uptake in primary food compartments (e.g., microbes associated with organic particles) could occur with precipitation and snowmelt events, and given the potentially high proportion of refractory materials (15-35\%; Rovira and Vallejo 2002), isotopic composition of consumers could be far from equilibrium at most times. We suspect that streams and wetlands would be intermediate between lentic and terrestrial systems in this regard.

The mismatch we observed between $\mathrm{N}$ isotopic labeling of sampled food sources and primary consumers is also relevant to studies of ecological stoichiometry. Such studies typically rely on sampling consumers and food resources using similar techniques as reported here. These values are then used to quantify the magnitude of elemental ratio mismatch between food and consumer, estimate threshold elemental ratios, and examine the consequences of dietary mismatches for consumer growth (e.g., Frost and Elser 2002, Frost et al. 2005). Our results suggest that most food sources for primary consumers in streams contain a substantial portion of $\mathrm{N}$ that is not assimilated, and it is possible that similarly refractory pools of carbon (and perhaps even phosphorus) also occur in primary food sources. If so, then the problems identified in this study may be exaggerated in stoichiometric studies since the relative size of labile and refractory pools is likely to vary across elements in a manner that would be difficult to quantify. To make things more difficult, different elements may be preferentially assimilated from different diet components. For example, stream invertebrates collected from Australia and New Guinea apparently took more of their $\mathrm{N}$ from algae in the stream but more of their carbon from terrestrially derived plant materials (Bunn et al. 2013).

Methods of separating relatively refractory $\mathrm{N}$ from actively cycling $\mathrm{N}$ in samples of basal food sources exist, and our results suggest that isotopic studies of food webs could benefit from application of such approaches. One 

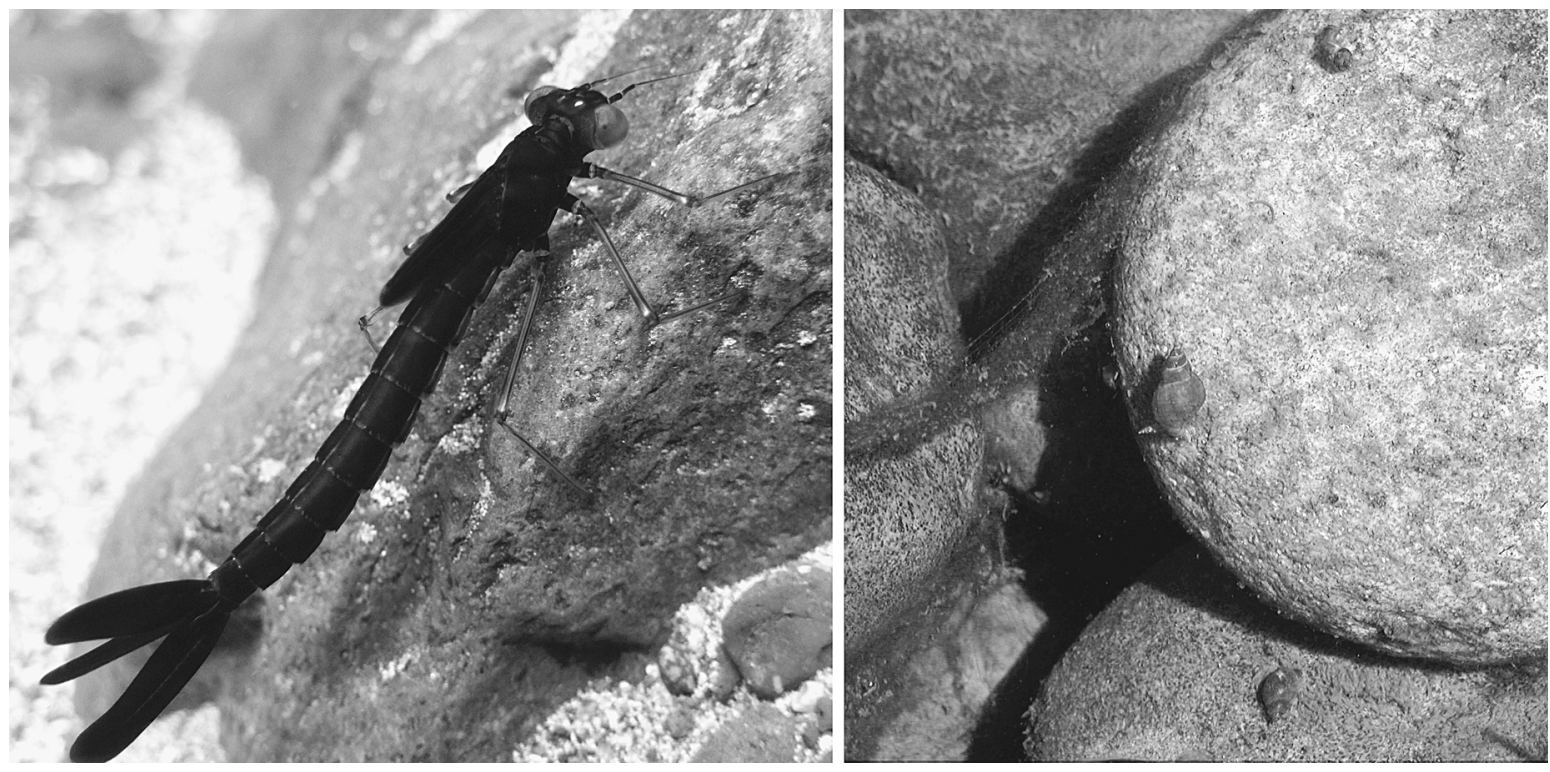

Plate 1. (Left) A damselfly nymph (Family Lestidae) in a mountain stream in Panama. Damselflies are important predators in streams and other aquatic habitats. (Right) Snails (Family Lymnaeidae) grazing on epilithic biofilms and associated filamentous green algae in the Teton Pines Waterway, an urban spring stream located in the Snake River basin, Wilson, Wyoming, USA. Photo credits: damselfly, Amanda T. Rugenski; snails, J. L. Tank.

approach previously discussed is to separate actively cycling biological material from other material using density gradient centrifugation in colloidal silica, which can yield a lighter fraction enriched in algae and/or bacteria (Hamilton et al. 2005). It might also be possible to select very rapidly growing materials to represent the food sources; Whiles et al. (2013) placed tiles in their study stream to provide a sample of rapidly accruing biofilm that more closely matched the maximum level of grazer labeling than did sampling of existing bulk epilithon. Bunn et al. (2013) used statistical correlations to assess the relative importance of food sources from field-derived data, but this requires results across a wide range of conditions. Finally, compound-specific (e.g., amino acid) isotope analyses hold considerable promise because they may be able to be optimized to reflect only actively cycling N (e.g., Evershed et al. 2007). Most separation techniques are more labor intensive and some are costly as well, but accurate characterization of food sources requires either physical separation of active food pools or modeling approaches similar to those described here.

Our study demonstrates the challenges associated with sampling and characterizing food resources for primary consumers (see Plate 1) whose presumed food sources are mixtures of actively cycling and refractory materials. We recommend that researchers consider ways to separate refractive from actively cycling materials, including those discussed in this paper. Incorporation of a multiplier to model relationships between food and consumers can account for the problem of a consumer having a higher ${ }^{15} \mathrm{~N}$ label than its presumed food source. Ecologists using isotopes as tracers in food webs, either through experimental isotope additions or natural abundance approaches, along with those conducting stoichiometric studies, should be cognizant of potential problems associated with sampling food sources that may not accurately represent what animals actually ingest and assimilate.

\section{ACKNOWLEDGMENTS}

We thank all the researchers involved in the isotopic release experiments that we report on; in particular, we are grateful to Pat Mulholland for his intellectual inspiration and fantastic leadership. The workshop that generated this paper was funded by grant DEB 1052399 by the U.S. National Science Foundation. This is contribution 14-334-J from the Kansas Agricultural Experiment Station. Partial support during manuscript preparation to N. A. Griffiths was from the Department of Energy's Office of Science, Biological, and Environmental Research. Oak Ridge National Laboratory is managed by UTBattelle, for the U.S. DOE under contract DE-AC0500OR22725. The manuscript has been authored by UT-Battelle, under Contract No. DE-AC05-00OR22725 with the U.S. Department of Energy. The United States Government retains, and the publisher, by accepting the article for publication, acknowledges that the United States Government retains, a non-exclusive, paid-up, irrevocable, world-wide license to publish or reproduce the published form of this manuscript, or allow others to do so, for the United States Government purposes.

\section{Literature Cited}

Altig, R., M. R. Whiles, and C. L. Taylor. 2007. What do tadpoles really eat? Assessing the trophic status of an understudied and imperiled group of consumers in freshwater habitats. Freshwater Biology 52:386-395.

Aluwihare, L. I., D. J. Repeta, S. Pantoja, and C. G. Johnson. 2005. Two chemically distinct pools of organic nitrogen accumulate in the ocean. Science 308:1007-1010. 
Ashkenas, L. R., S. L. Johnson, S. V. Gregory, J. L. Tank, and W. M. Wollheim. 2004. A stable isotope tracer study of nitrogen uptake and transformation in an old-growth forest stream. Ecology 85:1725-1739.

Benke, A. C., and J. B. Wallace. 1980. Trophic basis of production among net-spinning caddisflies in a southern Appalachian stream. Ecology 61:108-118.

Blumenthal, H. J., and S. Roseman. 1957. Quantitative estimation of chitin in fungi. Journal of Bacteriology 74: 222-224.

Bowen, S. H. 1987. Composition and nutritional value of detritus. Pages 192-216 in D. J. W. Moriarty and R. S. V. Pullin, editors. Detritus and microbial ecology in aquaculture. ICLARM Conference Proceedings 14. International Center for Living Aquatic Resources Management, Manila, Philippines.

Bunn, S. E., C. Leigh, and T. D. Jardine. 2013. Diet-tissue fractionation of $\delta^{15} \mathrm{~N}$ by consumers from streams and rivers. Limnology and Oceanography 58:765-773.

Cabana, G., and J. B. Rasmussen. 1996. Comparison of aquatic food chains using nitrogen isotopes. Proceedings of the National Academy of Sciences USA 93:10844-10847.

Cross, W. F., C. V. Baxter, E. J. Rosi-Marshall, R. O. Hall, T. A. Kennedy, K. C. Donner, H. A. W. Kelly, S. E. Z. Seegert, K. E. Behn, and M. D. Yard. 2013. Food web dynamics in a large river discontinuum. Ecological Monographs 83:311-337.

Crowl, T. A., W. H. McDowell, A. P. Covich, and S. L. Johnson. 2001. Freshwater shrimp effects on detrital processing and nutrients in a tropical headwater stream. Ecology 82:775-783.

Dodds, W. K., et al. 2000. Quantification of the nitrogen cycle in a prairie stream. Ecosystems 3:574-589.

Dodds, W. K., et al. 2004. Carbon and nitrogen stoichiometry and nitrogen cycling rates in streams. Oecologia 140:458467.

Elser, J. J., et al. 2000. Nutritional constraints in terrestrial and freshwater food webs. Nature 408:578-580.

Elton, C. 1927. Animal ecology. Sidgwick and Jackson, London, UK.

Evans-White, M., W. K. Dodds, L. J. Gray, and K. M. Fritz. 2001. A comparison of the trophic ecology of the crayfishes (Orconectes nais [Faxon] and Orconectes neglectus [Faxon]) and the central stoneroller minnow (Campostoma anomalum [Rafinesque]): omnivory in a tallgrass prairie stream. Hydrobiologia 462:131-144.

Evans-White, M. A., W. K. Dodds, and M. R. Whiles. 2003. Ecosystem significance of crayfishes and stonerollers in a prairie stream: functional differences between co-occurring omnivores. Journal of the North American Benthological Society 22:423-441.

Evershed, R. P., I. D. Bull, L. T. Corr, Z. M. Crossman, B. E. van Dongen, C. J. Evans, S. Jim, H. R. Mottram, A. J. Mukherjee, and R. D. Pancost. 2007. Compound-specific stable isotope analysis in ecology and paleoecology. Pages 480-540 in R. H. Michener and K. Lajtha, editors. Stable isotopes in ecology and environmental science. Blackwell Publishing, Malden, Massachusetts, USA.

Frauendorf, T. C., C. Colon-Gaud, M. R. Whiles, T. R. Barnum, K. R. Lips, C. M. Pringle, and S. S. Kulham. 2013. Energy flow and trophic basis of macroinvertebrate and amphibian production in a neotropical headwater stream. Freshwater Biology 58:1340-1352.

Frost, P. C., J. P. Benstead, W. F. Cross, H. Hillebrand, J. H. Larson, M. A. Xenopoulos, and T. Yoshida. 2006. Threshold elemental ratios of carbon and phosphorus in aquatic consumers. Ecology Letters 9:774-779.

Frost, P. C., and J. J. Elser. 2002. Growth responses of littoral mayflies to the phosphorus content of their food. Ecology Letters 5:232-240.
Frost, P. C., M. A. Evans-White, Z. V. Finkel, T. C. Jensen, and V. Matzek. 2005. Are you what you eat? Physiological constraints on organismal stoichiometry in an elementally imbalanced world. Oikos 109:18-28.

Fry, B. 1991. Stable isotope diagrams of freshwater food webs. Ecology 72:2293-2297.

Fry, B. 2006. Stable isotope ecology. Springer, New York, New York, USA.

Gerking, S. D. 1984. Fish as primary consumers: assimilation and maintenance ration of an herbivorous fish, Sarpa salpa, feeding on a green alga. Transactions of the American Fisheries Society 113:378-387.

Gessner, M. O., E. Chauvet, and M. Dobson. 1999. A perspective on leaf litter break down in streams. Oikos 85: 377-384.

Hall, R. O., J. B. Wallace, and S. L. Eggert. 2000. Organic matter flow in stream food webs with reduced detrital resource base. Ecology 81:3445-3463.

Hamilton, S. K., S. J. Sippel, and S. E. Bunn. 2005. Separation of algae from detritus for stable isotope or ecological stoichiometry studies using density fractionation in colloidal silica. Limnology and Oceanography Methods 3:149-157.

Hamilton, S. K., J. L. Tank, D. F. Raikow, E. Siler, N. J. Dorn, and N. Leonard. 2004. The role of instream vs. allochthonous $\mathrm{N}$ in stream food webs: modeling the results of a nitrogen isotope addition experiment. Journal of the North American Benthological Society 23:429-448.

Hamilton, S. K., J. L. Tank, D. F. Raikow, W. M. Wollheim, B. J. Peterson, and J. R. Webster. 2001. Nitrogen uptake and transformation in a midwestern US stream: a stable isotope enrichment study. Biogeochemistry 54:297-340.

Hawlena, D., and O. J. Schmitz. 2010. Herbivore physiological response to predation risk and implications for ecosystem nutrient dynamics. Proceedings of the National Academy of Sciences USA 107:15503-15507.

Jardine, T. D., et al. 2014. Understanding and overcoming baseline isotopic variability in running waters. River Research and Applications 30:155-165.

Laws, E. 1984. Isotope dilution modeled and the mystery of the vanishing ${ }^{15} \mathrm{~N}$. Limnology and Oceanography 29:379-386.

Layman, C. A., et al. 2012. Applying stable isotopes to examine food web structure: an overview of analytical tools. Biological Reviews 87:545-562.

Lindeman, R. L. 1942. The trophic-dynamic aspect of ecology. Ecology 23:399-418.

March, J. G., and C. M. Pringle. 2003. Food web structure and basal resource utilization along a tropical island stream continuum, Puerto Rico. Biotropica 35:84-93.

Martínez del Río, C., and R. Anderson-Sprecher. 2008. Beyond the reaction progress variable: the meaning and significance of isotopic incorporation data. Oecologia 156:765-772.

McCullough, B., and D. A. Heiser. 2008. On the accuracy of statistical procedures in Microsoft Excel 2007. Computational Statistics and Data Analysis 52:4570-4578.

McNeely, C., S. M. Clinton, and J. M. Erbe. 2009. Landscape variation in $\mathrm{C}$ sources of scraping primary consumers in streams. Journal of the North American Benthological Society 25:787-799.

Merriam, J. L., W. H. McDowell, J. L. Tank, W. M. Wollheim, C. L. Crenshaw, and S. L. Johnson. 2002. Characterizing nitrogen dynamics, retention and transport in a tropical rainforests stream using an in situ ${ }^{15} \mathrm{~N}$ addition. Freshwater Biology 47:143-160.

Minagawa, M., and E. Wada. 1984. Stepwise enrichment of ${ }^{15} \mathrm{~N}$ along food chains: further evidence and the relation between $\delta^{15} \mathrm{~N}$ and animal age. Geochimica et Cosmochimica Acta 48: 1135-1140.

Mulholland, P. J., J. L. Tank, D. M. Sanzone, W. M. Wollheim, B. J. Peterson, J. R. Webster, and J. L. Meyer. 2000. Food resources of stream macroinvertebrates determined by natural-abundance stable $\mathrm{C}$ and $\mathrm{N}$ isotopes and a 
${ }^{15} \mathrm{~N}$ tracer addition. Journal of the North American Benthological Society 19:145-157.

Nadelhoffer, K. J., M. R. Downs, and B. Fry. 1999. Sinks for ${ }^{15} \mathrm{~N}$-enriched additions to an oak forest and a red pine plantation. Ecological Applications 9:72-86.

Newbold, J. D., J. W. Elwood, R. V. O'Neill, and A. L. Sheldon. 1983. Phosphorus dynamics in a woodland stream ecosystem: a study of nutrient spiraling. Ecology 64:12491265.

Paine, R. 1966. Food web complexity and species diversity. American Naturalist 100:65-75.

Peterson, B. J., R. W. Howarth, and R. H. Garritt. 1985. Multiple stable isotopes used to trace the flow of organic matter in estuarine food webs. Science 227:1361-1363.

Peterson, B. J., et al. 2001. Control of nitrogen export from watersheds by headwater streams. Science 292:86-90.

Polis, G. A., and S. D. Hurd. 1995. Extraordinarily high spider densities on islands: flow of energy from the marine to the terrestrial food webs and the absence of predation. Proceedings of the National Academy of Sciences USA 92:43824386.

Rice, D. L. 1982. The detritus nitrogen problem: new observations and perspectives from organic geochemistry. Marine Ecology Progress Series 9:153-162.

Riis, T., W. K. Dodds, P. B. Kristensen, and A. J. Baisner. 2012. Nitrogen cycling and dynamics in a macrophyte-rich stream as determined by a ${ }^{15} \mathrm{~N}_{-} \mathrm{NH}_{4}{ }^{+}$release. Freshwater Biology 57:1579-1591.

Rosi-Marshall, E. J., and J. B. Wallace. 2002. Invertebrate food webs along a stream resource gradient. Freshwater Biology 47:129-141.

Rovira, P., and V. R. Vallejo. 2002. Labile and refractory pools of carbon and nitrogen in organic matter decomposing at different depths in soil: an acid hydrolysis approach. Geoderma 107:109-141.

Simon, K. S., C. R. Townsend, B. J. F. Biggs, W. B. Bowden, and R. D. Frew. 2004. Habitat-specific nitrogen dynamics in
New Zealand streams containing native or invasive fish. Ecosystems 7:777-792.

Simpson, S. J., R. M. Sibly, K. P. Lee, S. T. Behmer, and D. Raubenheimer. 2004. Optimal foraging when regulating intake of multiple nutrients. Animal Behaviour 68:12991311.

Tank, J. L., J. L. Meyer, D. M. Sanzone, P. J. Mulholland, J. R. Webster, B. J. Peterson, W. M. Wollheim, and N. E. Leonard. 2000. Analysis of nitrogen cycling in a forest stream during autumn using a ${ }^{15} \mathrm{~N}$-tracer addition. Limnology and Oceanography 45:1013-1029.

Vander Zanden, M. J., and J. B. Rasmussen. 1999. Primary consumer $\delta^{13} \mathrm{C}$ and $\delta^{15} \mathrm{~N}$ and the trophic position of aquatic consumers. Ecology 80:1395-1404.

Veuger, B., B. D. Eyre, D. Maher, and J. J. Middelburg. 2007. Nitrogen incorporation and retention by bacteria, algae, and fauna in a subtropical intertidal sediment: an in situ ${ }^{15} \mathrm{~N}$ labeling study. Limnology and Oceanography 52:1930-1942.

Webster, J. R., et al. 2003. Factors affecting ammonium uptake in streams: an inter-biome perspective. Freshwater Biology 48:1329-1352.

Wellard Kelly, H. A., E. J. Rosi-Marshall, T. A. Kennedy, R. O. Hall, W. F. Cross, and C. V. Baxter. 2013. Macroinvertebrate diets reflect tributary inputs and turbidity-driven changes in food availability in the Colorado River downstream of Glen Canyon Dam. Freshwater Science 32: $397-410$

Wetzel, R. G. 2001. Limnology: lake and river ecosystems, Third edition. Academic Press, San Diego, California, USA.

Whiles, M. R., et al. 2013. Disease-driven amphibian declines alter ecosystem processes in a tropical stream. Ecosystems 16: $146-157$.

Wollheim, W. M., B. J. Peterson, L. A. Deegan, M. Bahr, J. E. Hobbie, D. Jones, W. B. Bowden, A. E. Hershey, G. W. Kling, and M. C. Miller. 1999. A coupled field and modeling approach for the analysis of nitrogen cycling in streams. Journal of the North American Benthological Society 18: 199-221. 